\title{
Political Psychology
}

\section{How Riots Spread Between Cities: Introducing the Police Pathway}

\author{
John Drury \\ University of Sussex
}

Clifford Stott

Keele University

Roger Ball

University of Sussex

University of the West of England

Dermot Barr

University of Sussex

University of Manchester

Linda Bell

University of Sussex

Stephen Reicher

University of St Andrews

Fergus Neville

University of St Andrews

Waves of riots are politically and psychologically significant national events. The role of police perceptions and practices in spreading unrest between cities has been neglected in previous research, even though the police are significant actors in these events. We examined the role of police interventions in the spread of rioting to one English city in August 2011 by triangulating multiple data sources and analyzing police accounts and community-participant interviews. Rioting in other cities had relatively little direct influence in the community, but it led to heightened vigilance in the police. The resultant police mobilization inadvertently created a large gathering in a local community with a history of hostile relations with police. Police attempts to disperse the crowd affected many more people than those originally intending to riot, leading to collective conflict. These findings support a new theoretical account of the role of policing in riot spread. Complementing existing accounts of diffusion, our study helps explain how self-fulfilling prophecy can operate to spread conflict between cities.

KEY WORDS: riots, social identity, social influence, empowerment, police, civil unrest and PO Box 378 Carlton South, 3053 Victoria, Australia 
How does civil unrest spread from city to city? The protests and riots following the police killing of George Floyd in 2020 began in Minneapolis before spreading to other cities across the United States (Taylor, 2020). Structural preconditions (e.g., deprivation, police racism) help explain which cities riot. But research across a variety of disciplines-including history (Bohstedt \& Williams, 1988), sociology (Myers, 2010), economics (Aidt et al., 2017), political science (Midlarsky, 1978), and criminology (Baudains et al., 2013)—shows in addition that the occurrence of rioting makes riots in other cities more likely. What is less well understood is the social psychology underlying this diffusion process. In this article, we propose a novel theoretical framework to help explain mechanisms of riot diffusion between cities. Specifically, we examine the extent to which police concerns about the spread of rioting from elsewhere to their own jurisdiction can lead to a self-fulfilling prophecy. We examine the usefulness of this new framework through an analysis of a major riot that occurred as part of a national wave of unrest in England in 2011-in Salford, Greater Manchester. Using multiple data sources, we examined the extent to which the rioting in other cities increased expectations among police and community members that rioting would take place locally, how such expectations informed interaction between police and locals, and how that interaction became a riot.

\section{Group Processes in the Spread of Rioting}

In the last 10 years, major examples of civil disorder spreading between cities have been witnessed not only in the United Kingdom and the United States but around the world, including the Arab Spring in 2011, Chile in 2019, Hong Kong in 2019-20, and South Africa in 2021. The main explanations offered for such spread are contagion (e.g., Bauer et al., 2018; Kucharski, 2020; Slutkin, 2011) and communication among riot participants (e.g., Bohstedt \& Williams, 1988; Hobsbawm \& Rudé, 1969). Both of these types of explanations have a long history and an intuitive appeal. But both fail to address two fundamental questions of psychology: Why are some people more influential than others (Reicher, 1984), and why do some people and not others join in with the rioting (Milgram \& Toch, 1969)?

Recently, a social identity model of riot diffusion has been proposed which suggests that the people that are influential are those who are identity-relevant to those who join in (Drury et al., 2020). The model posits two pathways of influence. First, paralleling identity and injustice antecedents of collective action participation (e.g., van Zomeren et al., 2018), there is a cognitive pathway whereby shared social identity with those involved in antipolice rioting in other locations provides a normative motivation to do the same. Second, paralleling collective efficacy as an antecedent for collective action participation (Mummendey et al., 1999), there is a strategic pathway whereby the perceived vulnerability of a common outgroup (in this case the police) in other locations empowers potential participants. Mediating each of these pathways is a process of metaperception: People come onto the streets not only when they identify with others or are empowered by police weakness, but also when they believe that others locally identify or are empowered in these ways. This metaperception is the basis of expectations of support for ingroup normative actions (e.g., against the police and certain properties). The utility of the model was evidenced by its ability to explain both the boundaries and the sequence of diffusion in three London riots (Drury et al., 2020).

Like contagion and communication explanations, the social identity model of riot diffusion focuses principally on the perceptions and actions of crowd participants. But if the occurrence of rioting influences some members of the public in other cities, it might also influence the police. Police perceptions and actions are crucial in the lifecycle of riots (Marx, 1970; Newburn et al., 2018), and some forms of police intervention are known to escalate conflict (Stott \& Drury, 2000). Therefore, it is possible that the occurrence of rioting leads the police in other cities to act in ways which inadvertently produce (or at least accelerate) rioting. We turn now to the possible psychology of this "police pathway." 
Theorizing the Police Pathway of Riot Diffusion

One way of theorizing this police pathway of riot spread is by drawing on concepts from the elaborated social identity model (ESIM) of crowd conflict. The model explains the dynamic of conflict within events as in part a self-fulfilling prophecy arising from police perceptions of threat to public order. In this account, the police response to the perceived threat is to escalate coercive methods (e.g., use of riot-trained officers, horses, and batons) that are experienced by members of the crowd as both illegitimate and indiscriminate. Through uniting the crowd around a new norm of conflict against the police, the police intervention thereby creates the hostile crowd and public disorder that they feared (Stott \& Drury, 2000). ESIM dynamics are not restricted to U.K. contexts, with evidence now from four different continents in addition to the United Kingdom: North America (Maguire, Barak, et al., 2020), mainland Europe (Brechbuhl et al., 2020; Jetten et al., 2020), Asia (Stott et al., 2020), and Australia (Baker, 2020).

While ESIM research has largely been focused on within-event dynamics, we suggest here that a self-fulfilling prophecy could also operate between events. That is, rioting in other cities could create police concerns about the spread of disorder to their local context-particularly in those cities with a history of conflict with police. This could lead to police actions against local people who are not actually motivated by the events elsewhere but who become disorderly in response to the local police intervention.

Prima facie evidence for the role of a police self-fulfilling prophecy operating between locations comes from a study of the emergence of rioting in one district of London in 2011 (Stott et al., 2017). After rioting had taken place in the London district of Tottenham, police in nearby Hackney tried to preempt possible disorder locally by stopping and searching young Black men congregating on the streets. This intervention drew a crowd and eventually escalated into the very rioting the police had tried to prevent.

However, Stott et al.'s (2017) study of spread in London was very preliminary. It had little detail on process, and it lacked data from the police, so police perceptions and concerns were merely inferred not demonstrated empirically. Also, the spread was across two neighboring districts and involved the same police force. A key question is whether self-fulfilling prophecy might occur when the new location is many miles from the earlier rioting and involves different police forces as well as different communities than the earlier rioting. If so, this would help account for the nationwide spread of unrest. Finally, there is a need to examine how this police pathway interacts with processes of influence and spread in members of the public, as specified in the social identity model of riot diffusion.

\section{The Current Study}

In the study reported here, we investigate the development of a riot in Salford, Greater Manchester, which occurred as part of a significant national wave of unrest in England in August 2011. The first unrest took place in Tottenham, London, two days after the fatal shooting by police of a local mixedheritage man, Mark Duggan. Over the next 24 hours, rioting spread to other areas of London and the next day to several other cities in England. Altogether there were riot events in 89 different locations, with more than 4,000 arrests, and costs of up to $£ 500$ million (Riots, Communities and Victims Panel, 2011).

Our reasons for selecting Salford for the present analysis were threefold. First, prima facie the rioting there began following a police intervention (Clifton \& Allison, 2011). Second, it was significant in size; hundreds of people were involved, and there were $\sim 130$ reports of attacks on police, looting, and damage to property (Jeffery \& Tufail, 2015). Third, Salford is over 200 miles to the North of London, and the Salford riot was noncontiguous with other riots in the region; participants 
were overwhelmingly local people (Jeffery \& Tufail, 2015) who very likely had not been involved in the rioting in other cities.

Our overarching research question was: How did the rioting in other cities influence events in Salford? To address this, we had three specific objectives. First, based on the idea of selffulfilling prophecy, we addressed whether the rioting in London and elsewhere influenced local police concerns about the likelihood of disorder in Salford and the extent to which these concerns shaped preparatory and preemptive mobilization. Second, based on the social identity model of riot diffusion (Drury et al., 2020), we examined the extent to which the riots in other cities influenced local people to gather on the streets in Salford. Third, based on ESIM, we examined any asymmetries in police and community perceptions of an initial gathering: how the police's interventions were experienced by local people and how these experiences fed into a dynamic of conflict. We triangulated multiple sources to create a detailed account of the contours and timings of the Salford riot and then analyzed police and community participant perceptions before and during the events.

\section{Methods}

\section{Data}

We gathered contemporaneous and archive data from as many sources as possible, as well as interviewing community participants and witnesses, and obtained detailed accounts from police sources. This work was carried out as part of a larger investigation of the rioting in Greater Manchester as a whole (see the online supporting information).

Archive sources included newspaper articles, official reports (e.g., local authority), academic publications, and blogposts.

Contemporaneous sources included photos, tweets, videos, and audio files of BBC Radio Manchester's output of over 12 hours of live broadcast.

\section{Community Participant Interviews}

We had access to the Guardian/LSE (2011) Reading the Riots interviews gathered in the months immediately after the events in 2011. Local researchers working as part of the Reading the Riots project used their contacts to recruit people involved in the riots. Each interview was guided by the following topics: (1) when the participant first heard that something was going on; (2) what they first thought when they heard something was going on in their area/the place they traveled to; (3) why they thought people were getting involved; (4) where they went initially; (5) what they thought when they arrived; (6) in what way they became involved in what was happening; and (7) why they thought the riots or looting stopped. There were also questions about the possible role of social media and "gangs," whether the participant was involved in other events, and what they and others think of their involvement. Each interview lasted on average approximately 45 minutes. Two further community interviews were carried out by the fourth author of the present article, using a longer interview schedule that focused more on the interviewee's personal background. Of these 12 community interviewees, all were in the crowd during the riot and two admitted to being actively involved in the violence.

\section{Eyewitness Interviews}

We conducted five eyewitness interviews; four were with BBC Salford personnel on duty immediately prior and during the riot and one was with another local observer. 


\section{Police Material}

We drew upon a number of sources to reconstruct the perceptions and decisions of police. Contemporaneous sources included part of the police log of incidents (which recorded concerns, decisions, and actions before and during the events) and social media videos created by the police during the events as part of their communications with the public. We also drew upon the report of a formal inquiry into the policing of the 2011 conducted by Her Majesty's Inspectorate of the Constabulary (HMIC), the United Kingdom's police oversight body, which detailed local police concerns and actions. We also had a three-hour meeting with the Greater Manchester Police (GMP) Silver ${ }^{1}$ commander from the event and a colleague who was providing tactical advice on the night in question. They provided a detailed presentation on the timeline of the events (including extracts from contemporaneous decision logs), intelligence reports, and the nature of and rationale for key decisions. This meeting enabled us to closely question the commander on police thinking and decisions at the time.

Sources are summarized in Table 1, and full details are provided in the online supporting information.

$$
\text { Analysis }
$$

\section{Triangulation}

We systematically compared multiple sources to construct an account of events. Three types of information were used to substantiate the veracity of the timing, location, and content of events: postevent accounts by participants, police, and eyewitnesses; contemporaneous media; and physical evidence of the actions of the crowd (e.g., broken windows). A timeline of incidents was constructed in a spreadsheet from the collection, collation, and cross-referencing of discrete pieces of evidence. A narrative account was constructed from the timeline.

\section{Analysis of Police and Community Expectations and Perceptions}

For the analysis of police expectations and concerns, we used a combination of archive evidence and theoretically driven thematic analysis (Braun \& Clarke, 2006), concentrating on the contemporaneous data. We focused on how police talked about the disorder in other cities, their account of the local situation, and their decision-making. To understand participant experiences, we carried out thematic analysis of the 12 community-participant interview transcripts. This took place through several stages. First, two of the authors read all transcripts, noting issues that seemed to be important to interviewees. Second, one of us constructed an initial coding frame based on these notes and our research question and objectives. This included references to the riots in other cities, credibility of rumors, expectations of others' participation, curiosity, police illegitimacy, rights to be there, and the legitimacy of the initial gathering. All coded extracts were tabulated for ease of comparison across interviewees and themes.

\section{Ethics and Data Availability}

For the interviews we carried out, ethical clearance was given by the University of Sussex Science and Technology Research Ethics Committee, August 2018 (reference ER/HAFC1/4) and the University of Manchester Research Ethics Committee, January 2014 (reference 13296). For the community interviews, we redacted every interview transcript to remove any information that could make interviewees identifiable. The Reading the Riots corpus is available via the U.K. Data Service

\footnotetext{
"'Silver" in major incidents is the senior officer coordinating strategies undertaken by operational command on the ground.
} 


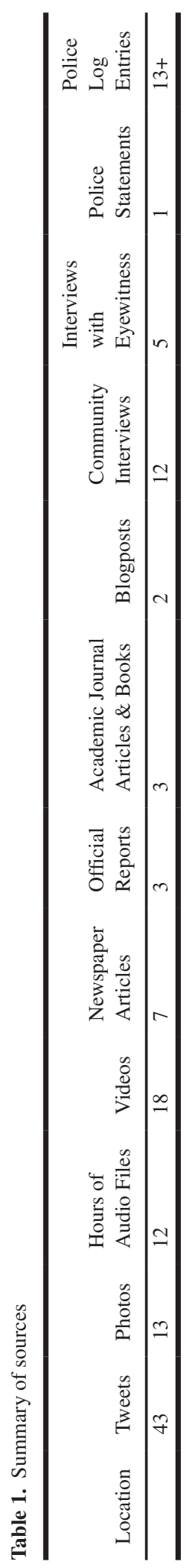


(reference https://doi.org/10.5255/UKDA-SN-853792). For other data used in the study, the online supporting information provides a complete list of publicly available sources.

\section{Overview of the Salford Riot}

The following summarizes the triangulated account of the Salford riot, which can be read in full in the online supporting information. Salford is a metropolitan borough in Greater Manchester, U.K. However, Salford is also a city in its own right with its own distinct identity, separated from the city of Manchester by the River Irwell. There are high levels of deprivation in the area, with a child poverty level of almost $75 \%$ in the districts affected by the 2011 rioting. In the last 30 years, there has been a polarization between the local population and the incoming middle classes (Jeffery \& Tufail, 2015; Morrell et al., 2011). There is also a significant history of contestation between police and communities in the area, including during the nationwide riots in 1981 (Hytner, 1981) and 1992 (Ford, 1992). Coordinated antipolice violence continued sporadically over the succeeding years in Salford, becoming increasingly associated with criminal gangs (Keeling, 2019).

On Tuesday, August 9, 2011, following the riots in other parts of the country, there were numerous rumors and predictions on social media of riots in Salford. Some shops in Salford closed early, from around 2 p.m. (While at least one put up a notice saying they had closed in response to police advice, there is no evidence that police gave such advice.) From around the same time, 20-30 youths began to congregate near the shopping center, known colloquially as the Precinct. In this period, there were reports of a broken window and looting. Police vehicles arrived at around 3:25 p.m., with sirens sounding. While the police found the reports of looting to be incorrect, they remained in the vicinity of the Precinct.

A growing crowd of people of all ages then gathered around the perimeter of the Precinct and across the road from the police. After some sporadic missile throwing toward the police, at 4:16 p.m. the riot-trained officers were ordered to try to disperse the crowd using long batons and dogs; they charged into the housing estate, and conflict then escalated. By 5:00 p.m., the number of those in conflict with police had increased to between 200 and 300, and the clashes had intensified. Despite sending in more officers, the police were outnumbered and came under heavy attack. By 6:00 p.m., the crowd had grown to around 1,000 people and had attacked certain property and vehicles.

Police made what they called a "tactical retreat" at 7:39 p.m. Shortly after this, a Lidl supermarket was looted by hundreds of people and set on fire. Looting had been steadily increasing, and now a number of shops were targeted at once. The types of properties that were vandalized, set alight, and looted included the supermarket, three pawnbrokers, a computer repair shop, a Chinese takeaway, a newsagent, and an off licence. The local MP's office was vandalized, as were three cars, two belonging to BBC journalists. Local houses were left untouched. Looting and damage to property continued, in spite of police reinforcements arriving at about 9:00 p.m., until around 11:00 p.m. Small-scale disturbances took place until the early hours of Wednesday, August 10, 2011.

Rioting in Manchester city center happened almost simultaneously with that in Salford (see the online supporting information). In terms of demographics, arrestees in the Greater Manchester area as a whole spanned a wide range of ages, but most were young working-class males and came from areas of high deprivation (Lightowlers, 2015). Arrest data are not necessarily representative, however, since "few arrests... were made in Salford due to the intensity of the violence police officers faced" (Jeffery \& Tufail, 2015, p. 44). 


\section{Analysis}

The analysis is structured to reflect our three objectives. In the first part, we analyze police expectations and preparedness leading up to the Salford riot, and in particular the possible influence of the rioting in other cities on their concerns and decisions locally. Second, we examine community participants' expectations and intentions before the riot, focusing on the possible influence on their actions of the rioting in other cities. Third, we analyze evidence for an asymmetry of representations in police and community perceptions of the initial gathering and the consequences of this asymmetry for police intervention and crowd response. We present extracts judged to be typical of each theme, and we indicate how common the theme is across the sample.

\section{Police Expectations and Preparedness}

As rioting spread across London on Sunday August 7 2011, there were two significant developments. First, there was criticism in the national news media of the police's "soft" approach, which had failed to prevent the rioting, and calls from the prime minister for more "robust" policing (e.g., Daily Mail reporter, 2011; Stott et al., 2017). Second, police forces around the country began mobilizing in preparation to respond to what they referred to as a "copycat" disorder (HMIC, 2011, p. 21).

According to the HMIC report, GMP was the second police force nationally that mobilized in response to the escalating situation. The force was in a relatively advanced state of preparedness to respond to any perceived threat of public disorder through a rapid, strong, and wellorganized public-order mobilization as they had participated in national exercises to test police public-order mobilization plans earlier that year (HMIC, 2011). On 9:00 a.m. on Monday, August 8, 2011, immediately following the riots in London, they launched Operation Valant (HMIC, 2011), which entailed mobilizing staff from other duties to populate police support units ${ }^{2}$ and actively seeking out any indicators of emerging tensions-as illustrated in the contemporaneous police-decision log:

In light of the ... disorder which has taken place in London over the weekend, [Assistant Chief Constable] Copley has asked that we ensure that GMP are in a position to respond to spontaneous disorder.

She has also directed that resources will be drawn from duty cover and officers not be placed on "standby."

(Contemporaneous police log, Monday, August 8, 2011)

On the one hand, GMP sent officers to London to assist police there (GMP, 2011; Nowell, 2011). On the other hand, the decision log indicates that GMP also took a number of proactive steps to prevent rioting developing locally. These included local information seeking in response to the spread of rioting from elsewhere:

monitoring tensions within communities due to disorder in London and copycat disorder in Birmingham, all divisions to make assessments on their divisions and report any tensions. (Contemporaneous police log, Monday, August 8, 2011, 8:21 p.m.)

\footnotetext{
${ }^{2} \mathrm{~A}$ police support unit is a mobile group of riot-trained police officers, typically comprising three vans containing 22 officers plus three drivers (College of Policing, 2018).
} 
Their responses also included communications to the public. That afternoon, they released a video, posted on YouTube, which warned several times that rioters would be "robustly" dealt with (GMP, 2011).

On Monday night, serious unrest spread outside of London for the first time, with major incidents in the West Midlands, Nottingham, Bristol, Leeds, and Merseyside. At 8:50 a.m. on Tuesday August 92011 , GMP recorded an array of "uncorroborated intelligence" that disorder might take place somewhere in Greater Manchester (meeting with Silver commander). This included social media posts that a riot was being planned at Salford Precinct and that a local police station would be attacked (Contemporaneous police log, Tuesday, August 9, 2011, 8:50 a.m.). In response to the expectation among police that disorder would take place locally, at 11:00 a.m. they held a Gold-level meeting, and subsequently there was a force-wide mobilization of public-order trained and other staff (meeting with Silver commander). By 2:00 p.m., they had established a Silver command center, a clear indication that senior commanders expected disorder (College of Policing, 2021). Operationally, this translated into the positioning of police support units around Greater Manchester including in the Salford area. Riot-trained officers waited in vans, wearing riot-protective uniforms, and were thus prepared to respond promptly to any signs of emerging disorder. Among the officers available were the force's highest trained public-order staff, the Tactical Aid Unit, as well as the force's dog unit (meeting with Silver commander).

In summary, therefore, evidence from multiple sources suggests that the spread of rioting in other cities led Greater Manchester Police to be concerned that disorder was increasingly likely to develop in their own jurisdiction. In response to the expected disorder, they prepared and mobilized including by priming and stationing riot-trained officers close to Salford.

\section{Community Expectations}

Most of our community interviewees referred, often spontaneously, to long-standing local hatred of police. They attributed this to a history of gratuitous police violence and street harassment against local people going back years and for which there was never any redress. This theme is significant: Poor community relations with police tends to distinguish those locations that join in with waves of rioting from those that do not (e.g., Baudains et al., 2013). However, there was little evidence that our community interviewees saw the police killing of Mark Duggan or the rioting in London as selfrelevant. Indeed, a number of them explicitly denied the influence of the rioting in London on local events, saying that it was not relevant to Salford people. Thus, this interviewee states that he doesn't understand why the riots happened in Salford following those in London since London is "far away":

It's just like... I can't answer that question you know. It is far away innit London, but I don't get-I don't know why-it travelled. Like if there's a riot there, why did it have to come here, you know what I'm saying? I don't get that myself, yeah. (SAL2710112406 221-226) ${ }^{3}$

Five of the community interviewees, including the two who admitted they were actively involved, said that once the rioting started happening in cities in the North of England, nearer Salford, they did expect people locally to riot. Thus, one of the active participants states that, while he discounted the events in London, once the rioting happened in Toxteth (in nearby Liverpool), he expected it to happen locally. His description of the "electric atmosphere" on the Precinct suggests excited anticipation on his part as well as his perception that other people likewise expected something to happen on the Precinct:

I thought it was just a one-night thing in Tottenham, then by Monday, it was going on everywhere and when I went to bed on Monday night, I was watching it it got to Toxteth and I

\footnotetext{
${ }^{3}$ The reference is to the transcript name and the line number(s).
} 
thought well it's definitely going off in Manchester tomorrow, no doubt about it, and then on the Tuesday it was electric, it was all through the midday, in the morning you could tell something was gonna happen, everyone was out on the street, even like young mums and kids and all that, just everyone, you know there was an atmosphere, you could feel it, that it was gonna go off. (MAN2310119905 15-21)

These five participants also believed the numerous rumors that people would come onto the streets in Salford. One of our community interviewees who admitted active participation in the rioting said the rumors led him to expect other people to gather at the Precinct, which in turn led him to go there:

in the morning, there was a rumour going round, first thing in the morning like was getting text around that all the lads on my side were gonna come and do a Precinct (?) ${ }^{4}$ so like, we were doing that because it was less on top [risky] than it would in town [Manchester] (?), be less cameras, that sort of thing, easy to get away. ... so that was the main thing in the morning, then everyone got out here about half two. (MAN2310119905 27-33)

However, in the case of half of our community interviewees, there was no evidence that the rioting in other cities had any influence on them. For them, the rioting in Salford was explained solely in terms of the local relationship with police — both historically and on the day. Therefore, the rioting elsewhere was irrelevant.

Thus this 43-year-old male interviewee denies that Salford was part of the national wave of riots. Rather, the rioting locally was solely due to the local police intervention on the day:

A: "Well if the police wouldn't have been there, it wouldn't have happened, simple as that."

Q: "Do you not think the looting would have happened?"

A: "No."

Q: "Why not, because it was happening in other places, it happened down the road in Manchester."

A: "Well for a start there is nothing to rob on Salford Precinct, there's one reason."

(SAL1110112702 539-548)

These community interviewees also discounted the many rumors that rioting would happen in Salford. For example, this interviewee says that when he saw the shops shutting on the Precinct, he dismissed this as an overreaction to these rumors:

A: "em, I'd says a few days before the riot began, em, a friend of mine from a place called Witney in Oxfordshire, emailed me and said 'is everything OK', and I said 'yeah why', and they said 'yeah there's going to be riots in Salford' and I said 'no there's nothing happening, it's fine', and so I brushed it off [ ]"5

Q: "When you first heard that something was going on in Salford, you saw the shutters closing down, how did it make you feel?"

A: "I didn't think anything of it, I thought they were just being overprecautious, erm, I just carried on with my day. I went shopping, and em, yeah, no, I wasn't worried."

\footnotetext{
${ }^{4}(?)$ indicates utterance is unclear.

${ }^{5}$ Empty square brackets indicate that some text has been edited out to save space.
} 
(SAL1410112402 9-18, 25-29)

In summary, despite long-standing hostility to the police in the community, there was little evidence from our interviews that the events in London were widely seen as self-relevant. There was a mixture of reactions to the rioting in other cities. For some community interviewees, the riots in other Northern cities led them to believe the rumors and to expect other people to participate locally. They were among the small group that felt sufficiently encouraged by the riots in other cities to gather in the Precinct. However, other community interviewees did not perceive any of the other riots as self-relevant, they dismissed the rumors, and they did not expect others locally to gather on the streets.

\section{Dynamics of Escalation}

\section{Community Perceptions of the Gathering}

One of the two community interviewees who admitted taking an active part in the violence described the people gathering in the Precinct area as "up to no good" (MAN2310119905, 114), indicating their intentions to participate in rioting. In contrast, however, most community interviewees stressed the harmlessness of the gathering. Thus interviewees used terms such as "nothing" or "normal" to describe the behavior of people in the Precinct area. These comments referred to both the minor incidents from 2:00 p.m. onwards as well as the larger gathering at 4:00 p.m. that the police attempted to disperse.

For example, an interviewee repeats there was "nothing happening at all" in the period just before the police intervention; it was a "normal day," and those present were both small in number and young, both of which imply lack of threat:

A: "I went to the precinct at two o'clock and there was nothing happening at all. Nothing"

Q: "Nothing as in it was a normal day or nothing as in..."

A: "It looked like a normal day and what happened was, there was I'd say about 20 kids in hoodies just across the road from the Precinct sat there and the police were kinda patrolling."

(S1m1 265-269)

Another male interviewee similarly minimizes the significance of the scene before the police intervention:

Q: "Tell me what you saw."

A: "What did I see? Just like, people just messing around."

(SAL2710112406 38)

Likewise, this male interviewee states that, even though those gathered at the Precinct were masked, they weren't doing anything beyond "just gathering" itself. Hence their behavior was normal, legitimate, and again harmless:

Q: "You say you didn't recognize anybody there cause they were all covered up, but what were they doing at that point?"

A: "They weren't really doing anything at that point, three o'clock."

Q: "Just gathering?" 
A: "Just gathering, yeah."

(SAL2710112408 56-66)

Six community interviewees stated that they were present in the Precinct area from the start of the conflict, while two stated that they only arrived when the conflict had already begun. Across the interviews, there was a theme of 'curiosity', as interviewees described their presence as innocuous; rather than seeking conflict, people attended simply to see what was going on. Most of those who referred to curiosity talked about it in response to the behavior of the police on the day: The police had come to the estate in force, and local people wanted to see what was going on because of this. Some interviewees referred to the curiosity motive of others around them or the fact that people were now being drawn to the area by the presence of the police. Others said it was the developing conflict itself that drew them to the gathering. This pattern of responses is consistent with the suggestion that the initial police incursion, while not itself conflictual, drew many more people into the location and turned a small (homogeneous) gathering into a growing (heterogenous) crowd. It was in this context of a growing crowd that the police attempted dispersal.

\section{Police Perceptions of the Gathering}

Over the course of a few hours, police perceptions of the gathering changed from initially being similar to those of the community interviewees to being clearly asymmetrical to them. Thus, the contemporaneous police log at 4:00 p.m. refers to "nothing going on" in Salford Precinct, echoing almost exactly the wording used by community interviewees. However, after this point, police accounts changed to contrast sharply with those of the community. Now police stressed the threat posed by some people in the crowd-as reflected in the language used in the contemporaneous log: "causing problems," "attack," and "looting":

1609_-Youths at side of houses ... appear intent on causing problems.

1616-Patrols under attack by people throwing bricks [ ]

Emergency button activated looting going on in Salford precinct.

(Contemporaneous log, Tuesday, August 9, 2011)

From the perspective of police commanders, a number of people in the crowd were now not only intent on "causing problems" but were "arming" and "throwing missiles," and their number was growing:

161330 hooded up

Picking up block paving arming selves

[ ] youths gathering in numbers around Salford and recreation areas [ ]

CCTV of youths throwing missiles and carrying sticks

(Contemporaneous log, Tuesday, August 9, 2011)

It was at this point that the Silver commander ordered police to "disperse the crowd and prevent them gathering in larger groups" (meeting with Silver commander). Significantly, therefore, both the methods (dispersal) and the language (a "crowd") related not just to the particular individuals seen to be "arming" themselves or throwing missiles, but to the whole gathering. Moreover, given 
their prior preparedness, police had the capacity to intervene to ensure that their dispersal action did address the whole crowd.

\section{Community Responses to the Police Intervention}

There was a common pattern in community interviewees' accounts of the police attempt at dispersal-that it was an illegitimate attack on them and was disproportionate to any perceived wrongdoing within the crowd. Though not all our community interviewees said this, no one contradicted it. In the following, for example, a 43 -year-old male interviewee contrasts the "small incident" of a window being broken and " 15 kids" with the large number of police. The police's behavior is said to be "over the top," and they "bang their shields" threateningly at vulnerable groups: "women, kids, and prams":

first small incident, window broke on the Precinct and then there was about 16 police vans, totally over the top blocked the road off and there must have been about 15 kids on bikes who live on the estate who can see out of the flats, they live there, its summer holidays, they are riding around they wear hoodies, black, grey, white, whatever, it's fashion. Next thing about 40, and I have photos on my phone, about 40 police like something out of a war film, full combat gear, straight in. It's more of a close rather than a street, now what you gonna do, if there are 40 police officers banging their shields in broad daylight, four o'clock, there are women and kids sitting about with prams. (SAL1110112702 31-38)

Interviewees described the police action in various ways that implied it was disproportionate and illegitimate, again including contrasts between the size of the police ('massive') and the vulnerability of those they were aggressively confronting:

And then three massive coppers in front of us who just pushed us out of the way. There was no need to do that, it was just two girls. You know what I mean, instead of saying 'you can't go through can you please go', they was shoving you, 'no you're not going through', pushing you out of the way. (SAL2710112407 125-128)

This police behavior led to what was described as 'retaliation' - it created the conflict rather than reduced it, according to this interviewee:

The police made it worse than anyone else, they were just running at the kids and everything and the dogs. So they were retaliating and running back at the police.

[]

some of the kids these days, they are out of order. But the police made it worse.

(SAL2710112407 22-23, 81)

Other interviewees described how those gathered in the vicinity had a right to be there, and as such it was illegitimate for the police to try to move people. The following comment suggests police action was experienced as indiscriminate as well as illegitimate, since even local bystanders were targeted, not just those in the initial gathering:

next thing all these vans turned up all the riot police came down and they really started harassing people and 'but why should I move?', they was even doing that to people who lived on the close 
get in your house, 'well hang on, I live on the close, you are the ones who have come here'. (SAL1110112703 541-555)

Given that interviewees saw the police interventions as illegitimate, they said fighting back against them was legitimate. Indeed, it was appropriate self-defence, according to this 43 -year-old male interviewee:

people have got a right to defend themselves even if it is against the police. (SAL1110112702 131-132)

For this 46-year-old man, the illegitimate police action transformed him from a mere spectator to a participant, a process he also observed in others:

they wasn't rioters they were just spectators that was drawn in. Like I was a spectator right, but what I saw of the police, made me want to get involved. [ ]

everybody watching it who got involved afterwards, who didn't want to get involved until they saw the police tactics and they are like 'hang on they are being a bit fucking cheeky', you know, like. (SAL1110112703 541, 562-564)

Several community interviewees disapproved of the looting; and some maintained that the police had deliberately staged the conflict in Salford to keep rioters away from Manchester city center. Therefore, by no means did everyone feel positive about the escalation of the conflict. Nevertheless, as people described how the fightback became a rout of police, a common theme across the interviews was that of empowerment. Thus, there were references to people being "strengthened," to exhilaration ("buzz"), joy ("best day of my life," "fun"), delight ("chuffed"), the perception that "everyone" was joining in, as well as to pride in the local identity:

cause you think 'wow, we're powerful, people are powerful'. The people are powerful, when you get together like that [ ] the police just got absolutely outrun, they were say 10-15 riot vans and they was all backing off. Every riot van got backed off by a crowd of 3-400 people charging at 'em 'Salford! Salford! Salford!' it was absolutely, they shit themselves, absolutely shit themselves [ ] They got absolutely outrun, they got battered and they didn't have an answer and the people of Salford thought 'we've won'. And they [local people] took over the city, they done what they wanted. .... It weren't just gangs of lads, it was mams dads, granddads, nanas running in places getting things, crazy. (S2ma 530-538, 557-561)

Figure 1 provides a schematic representation of the key factors identified in the analysis and how they relate to each other. While the rioting in other cities influenced both the police and the community, the likelihood that this translated into rioting locally was conditional on a number of factors: local history, police intervention, self-relevance, and the nature of the gathering. In addition, the figure illustrates that the gathering and the police intervention can influence each other.

\section{Discussion}

There is evidence that the riots in other cities influenced events in Salford in August 2011. The riots in other cities led police in Greater Manchester to mobilize for conflict. In the days leading up to the Salford events, their concerns about "copycat" rioting led them to be organizationally and psychologically primed to respond to possible signals of emerging disorder locally. On the day, riot-trained officers were stationed nearby Salford Precinct in readiness. Among 


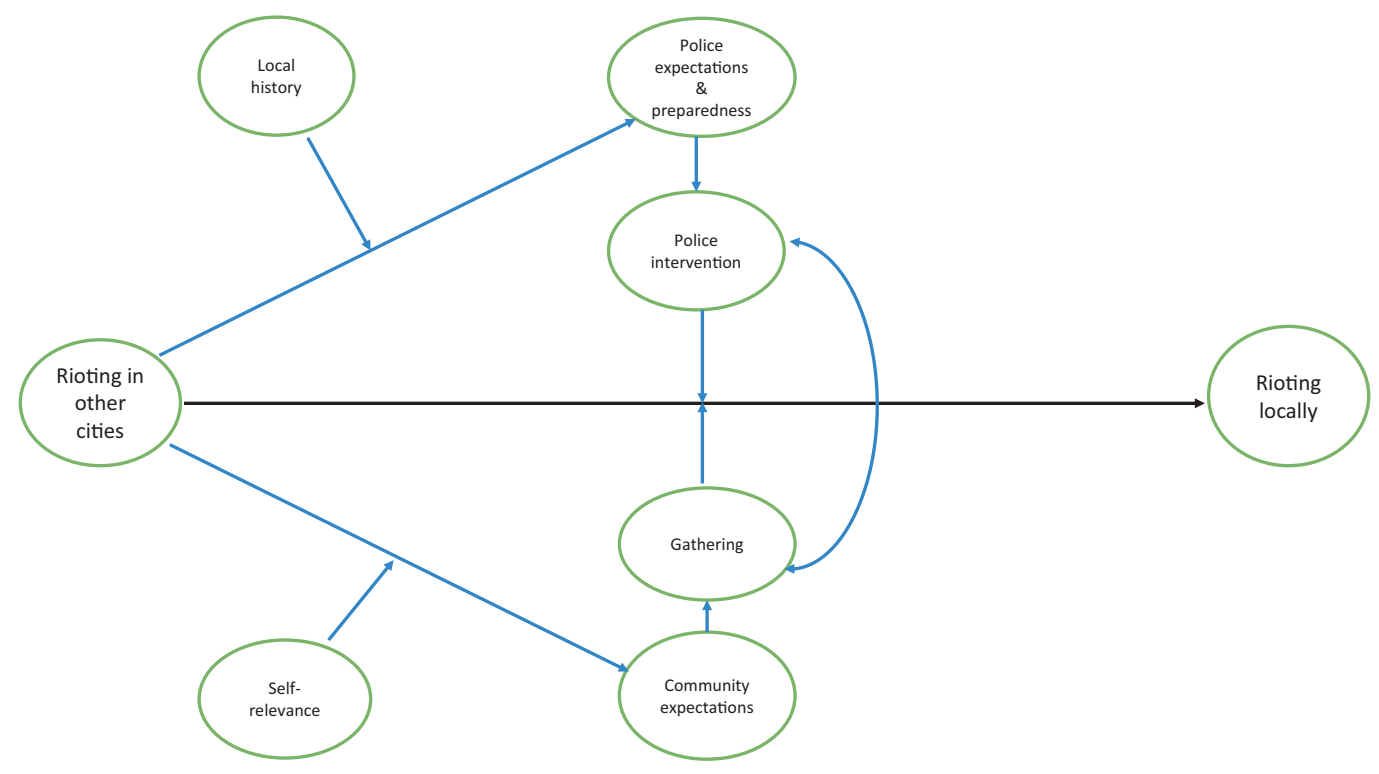

Figure 1. Schematic representation of interaction of police pathway and community responses.

members of the community, however, the impact of the rioting in other cities was mixed. For some, the rioting in nearby cities led them to expect people to come onto the streets in Salford, which in turn encouraged them to do the same. But around half of the community interviewees saw no connection between riots elsewhere and their own situation, and they had no expectation that there would be rioting locally. Crucially, the evidence from the community interviews aligns with the triangulated evidence that the initial gathering in Salford was small and became much larger only after the arrival of the police. In other words, our data suggests the police's concerns about likely copycat rioting led them to mobilize into Salford in a way that inadvertently brought larger numbers of people onto the streets. The police's failed attempt to forcibly disperse this crowd was experienced by people in the crowd as illegitimate, which legitimized fighting back. The dispersal attempt also had the effect of psychologically uniting those who were there simply out of curiosity with those who sought conflict, empowering the crowd as a whole to confront the police.

Behavior in the community wasn't simply a response to the police. A small number of people gathered around the Precinct hoping for a riot, and some of them initiated throwing missiles at police. But without the police actions, the gathering may not have attained the necessary critical mass for a full-scale riot. At the very least, our data suggest the police mobilization and attempted dispersal, based on their concerns about "copycat" rioting, accelerated the occurrence and increased the scale of rioting in Salford. It was in this sense a self-fulfilling prophecy.

The fact that people in Salford were exposed to news about the riots in other cities but only a small number of those we interviewed saw these events as relevant and were influenced to do the same is inconsistent with the concept of "contagion" (e.g., Bauer et al., 2018; Kucharski, 2020; Slutkin, 2011). Information was important as a pathway of spread in Salford, in line with the notion that communication processes are the basis of riot diffusion (e.g., Hobsbawm \& Rudé, 1969). But the evidence of differential responses to the rumors indicate that participants' definition of the local 
identity, their perceived connection to other cities (e.g., "I was watching it it got to Toxteth and I thought well it's definitely going off in Manchester tomorrow" MAN2310119905, above), and, crucially, their metaperceptions regarding relevant others locally were key to which information people listened to and which they discounted. This pattern of evidence is therefore more consistent with the social identity model of riot diffusion (Drury et al., 2020) than with contagion and other accounts.

The role of police actions in the escalation of rioting has been demonstrated previously. However, this previous work has examined the role of the police within rather than between riots (e.g., Stott \& Drury, 2000). Or it has analyzed spread between contiguous locations (e.g., Baudains et al., 2013; Stott et al., 2017). In this study, we have shown the value of using psychological concepts to help understand a much more complex form of diffusion — that is, to a city many miles from the original rioting.

As well as the importance of heightened police vigilance and preparedness in explaining the spread of riots, the present analysis suggests the following factors are critical and are not simply perceptual but also fundamentally practical. First, there is local history. Those towns and cities that rioted in England in August 2011 were often the same locations that had rioted in previous waves. A local history of conflictual relations with police was mentioned by most community interviewees as the context to the events, and the gathering in response to the police mobilization appears to be a function of that history. Police concerns-including their heightened state of vigilance-were also conditioned by local history. The organizational awareness of long-standing antipolice contestation was perfectly illustrated in our meeting with the Silver commander who contextualized the conflict as: "Salford: History of antagonism towards Police." We suggest that it is police forces in those areas with a history of conflict where a self-fulfilling prophecy is more likely.

Second, police capacity-which translates psychologically as group efficacy (Mummendey et al., 1999)—crucially affects the response. GMP had been involved in public-order exercises earlier in the year; possibly, without that level of preparedness and the personnel available to them they could not have mobilized and intervened in the way they did.

\section{Strengths, Limitations, and Future Work}

A strength of the present study is the depth and breadth of data, including contemporaneous sources (videos, log) and data from the different groups involved (police, participants, witnesses). An obvious difference between police and community participants is that in the former but not the latter there is hierarchical organization. This means that the perceptions and decisions of the police leadership were critically important in understanding the collective behavior of the police. It is a strength of this study that we managed to get detailed statements from the most senior police commander on the day. It should also be noted that this evidence can be considered conservative; if the commander's account did contain bias, then it is likely this would tend to be towards playing down a key argument of the article- that policing escalated or even caused the Salford riot.

A criticism might be that only a minority of community interviewees admitted to active involvement in the violence. However, there was evidence of change in definitions of legitimate conduct (towards supporting the violence against police) across the community sample, and that change in legitimacy is the key theoretical concern. It is also possible that community interviewees' accounts might be post hoc rationalizations of actions rather than reflections of motives and feelings operating at the time. Yet in the present case, the fit between the pattern of interview responses and the details of the triangulated account give us confidence that interview statements were largely authentic. The similarity of the accounts of our participants to those in Jeffery and Tufail's (2015) study of the same event further attests to their validity.

Where police fail to prevent rioting, this may be seen by others (media, politicians, other police officers) as a failure of their core duties; so police commanders would "die in a ditch" to prevent disorder 
from happening (Waddington, 1993). Recent observations from the United States suggest that the pattern of police responses observed in our study is not restricted to the United Kingdom. Police were publicly criticized for underresponding at the 'Unite the Right' protests in Charlottesville in 2017. Two weeks later, they overresponded by firing chemical munitions and projectiles at a mostly peaceful crowd protesting against President Trump in Arizona, leading to numerous injuries in vulnerable people (Maguire, Khade, et al., 2020). Police accountability dynamics are clearly highly consequential and therefore need to be better understood. There are parallels here with aspects of signal detection theory (e.g., Wormwood et al., 2016). In this account, high-profile criticisms of police for under-responding change the criterion level such that the costs to police of false negatives (i.e., under-responding to potential disorder) become seen as increasingly serious. This increases the pressure to act and the likelihood of making false positives - such as preemptive (violent) interventions against (otherwise peaceful) crowds. Future work could therefore usefully examine the extent to which the police pathway is driven by changes in police perceptions of the costs of false negatives during a wave of riots.

\section{Conclusions}

In waves of civil unrest-including recent examples such as the Black Lives Matter movementstructural injustices and histories of antagonism explain which cities riot, but not when they riot. What is needed to explain how riots spread is an account of the psychological effect on police and communities of riots in other cities, which we provide here. In the police pathway, riots in other cities increase police vigilance in those cities with a history of contestation. In this context, police become primed to act preemptively and coercively. Police preemptive mobilization may draw a crowd, inadvertently expanding the numbers on the streets beyond the initial minority activity seeking conflict. Where there is an asymmetry of representations of legitimate conduct between police and community, police intervention can lead to escalation and conflict, involving local people not otherwise influenced by the riots in other cities.

\section{ACKNOWLEDGMENTS}

This work was supported by a grant from the Economic and Social Research Council (grant number ES/N01068X/1) to John Drury, Stephen Reicher, and Clifford Stott. We would like to thank the following people: Tim Newburn for access to the Guardian/LSE Reading the Riots interview dataset; Rob Procter and Hamish Lacmane for access to and assistance with the Twitter data; and Evans Ndiema and Cassie Lowery for assistance in developing the triangulated account. Correspondence concerning this article should be addressed to John Drury, School of Psychology, University of Sussex, Falmer Brighton BN1 9QH, UK. E-mail: J.Drury@ sussex.ac.uk

\section{REFERENCES}

Aidt, T., Leon, G., \& Satchell, M. (2017). The social dynamics of riots: Evidence from the Captain Swing riots, $1830-31$. Working Paper, Cambridge University.

Baker, D. (2020). Public order policing approaches to minimize crowd confrontation during disputes and protests in Australia. Policing: A Journal of Policy and Practice, 14(4), 995-1014. https://doi.org/10.1093/police/paz071

Baudains, P., Johnson, S. D., \& Braithwaite, A. (2013). Geographic patterns of diffusion in the 2011 London riots. Applied Geography, 45, 211-219. https://doi.org/10.1016/j.apgeog.2013.09.010

Bauer, M., Cahlíková, J., Chytilová, J., \& Želinský, T. (2018). Social contagion of ethnic hostility. Proceedings of the National Academy of Sciences, 115(19), 4881-4886. https://doi.org/10.1073/pnas.1720317115

Bohstedt, J., \& Williams, D. E. (1988). The diffusion of riots: The patterns of 1766, 1795, and 1801 in Devonshire. Journal of Interdisciplinary History, 19(1), 1-24. https://doi.org/10.2307/204221 
Braun, V., \& Clarke, V. (2006). Using thematic analysis in psychology. Qualitative Research in Psychology, 3(2), $77-101$. https://doi.org/10.1191/1478088706qp063oa

Brechbuhl, A., Schumacher-Dimech, A., \& Seiler, A. (2020). Policing football fans in Switzerland: A case study involving fans, stadium security employees, and police officers. Policing: A Journal of Policy and Practice, 14(4), 865-882. https://doi.org/10.1093/police/pax086

Clifton, H., \& Allison, E. (2011, December 6). Manchester and Salford: A tale of two riots. Guardian. https://www.thegu ardian.com/uk/2011/dec/06/reading-the-riots-manchester-salford

College of Policing. (2018). Public order: Tactical options. https://www.app.college.police.uk/app-content/public-order/ planning-and-deployment/tactical-options/

College of Policing. (2021). Public order. Command. https://www.app.college.police.uk/app-content/public-order/ command/

Daily Mail reporter. (2011, August 15). So where WERE police? Shopkeepers mystified at tactics that left them defenceless. Daily Mail. https://www.dailymail.co.uk/news/article-2023984/London-riots-2011-Where-police-Shopkeepers-mysti fied-theyre-left-defenceless.html

Drury, J., Stott, C., Ball, R., Reicher, S., Neville, F., Bell, L., Biddlestone, M., Lovell, M., Choudhury, S., \& Ryan, C. (2020). A social identity model of riot diffusion: From injustice to empowerment in the 2011 London riots. European Journal of Social Psychology, 50(3), 646-661. https://doi.org/10.1002/ejsp.2650

Ford, R. (1992, July 24). Police say media are overstating violence. The Times.

Greater Manchester Police. (2011, August 9). Update on the ongoing situation in Manchester [YouTube video]. https://www. youtube.com/watch?v=7XztMQTrXQA

Guardian/LSE. (2011). Reading the riots: Investigating England's summer of disorder. https://www.researchgate.net/publi cation/277230578_Reading_the_Riots_Investigating_England's_Summer_of_Disorder

Her Majesty's Inspectorate of Constabulary. (2011). The rules of engagement. A review of the August 2011 disorders. HMIC.

Hobsbawm, E., \& Rudé, G. (1969). Captain Swing. Phoenix Press.

Hytner, B. A. (1981). Report of the Moss Side enquiry panel to the leader of the Greater Manchester Council. Greater Manchester Council.

Jeffery, B., \& Tufail, W. (2015). 'The riots were where the police were': Deconstructing the Pendleton riot. Contention, 2(2), 37-55.

Jetten, J., Mols, F., \& Selvanathan, H. P. (2020). How economic inequality fuels the rise and persistence of the Yellow Vest movement. International Review of Social Psychology, 33(1), 2. https://doi.org/10.5334/irsp.356

Keeling, N. (2019, January 20). How a young Salford firebrand rose to become one of Britain's most feared hard men. Manchester Evening News. https://www.manchestereveningnews.co.uk/news/greater-manchester-news/paul-masseymr-big-salford-15691678

Kucharski, A. (2020). The rules of contagion. Profile books.

Lightowlers, C. L. (2015). Let's get real about the 'riots': Exploring the relationship between deprivation and the English summer disturbances of 2011. Critical Social Policy, 35(1), 89-109. https://doi.org/10.1177/0261018314545597

Maguire, E. R., Barak, M., Wells, W. H., \& Katz, C. (2020). Attitudes toward the use of violence against police among Occupy Wall Street protesters. Policing: A Journal of Policy and Practice, 14(4), 883-899. https://doi.org/10.1093/polic e/pay003

Maguire, E. R., Khade, N., \& Mora, V. (2020). Improve the policing of crowds. In C. Katz \& E. R. Maguire (Eds.), Transforming the police: Thirteen key reforms. Waveland Press.

Marx, G. T. (1970). Civil disorder and the agents of social control. Journal of Social Issues, 26(1), 19-57.

Midlarsky, M. I. (1978). Analyzing diffusion and contagion effects: The urban disorders of the 1960s. American Political Science Review, 72(3), 996-1008. https://doi.org/10.2307/1955117

Milgram, S., \& Toch, H. (1969). Collective behavior: Crowds and social movements. In G. Lindzey \& E. Aronson (Eds.), The handbook of social psychology (2nd ed., Vol. 4, pp. 507-610). Addison-Wesley.

Morrell, G., Scott, S., McNeish, D., \& Webster, S. (2011). The August riots in England: Understanding the involvement of young people. NATCEN.

Mummendey, A., Kessler, T., Klink, A., \& Mielke, R. (1999). Strategies to cope with negative social identity: Predictions by social identity theory and relative deprivation theory. Journal of Personality and Social Psychology, 76(2), 229-245. https://doi.org/10.1037/0022-3514.76.2.229

Myers, D. J. (2010). Violent protest and heterogeneous diffusion processes: The spread of US racial rioting from 1964 to 1971. Mobilization: An International Quarterly, 15(3), 289-321. https://doi.org/10.17813/maiq.15.3.f162041086 $31474 \mathrm{v}$ 
Newburn, T., Diski, R., Cooper, K., Deacon, R., Burch, A., \& Grant, M. (2018). 'The biggest gang'? Police and people in the 2011 England riots. Policing and Society, 28(2), 205-222. https://doi.org/10.1080/10439463.2016.1165220

Nowell, A. (2011, August 9). Riot rumours circulate and police vans arrive in Piccadilly Gardens. Mancunian Matters. http:// www.mancunianmatters.co.uk/content/090855969-manchester-remainstense-riot-rumours-circulate-and-police-vansarrive-piccadilly

Reicher, S. D. (1984). The St Pauls' riot: An explanation of the limits of crowd action in terms of a social identity model. European Journal of Social Psychology, 14, 1-21. https://doi.org/10.1002/ejsp.2420140102

Riots, Communities and Victims Panel. (2011). 5 Days in August: An interim report on the 2011 English riots.

Slutkin, G. (2011, August 14). Rioting is a disease spread from person to person-The key is to stop the infection. Guardian. https://www.theguardian.com/uk/2011/aug/14/rioting-disease-spread-from-person-to-person

Stott, C., \& Drury, J. (2000). Crowds, context and identity: Dynamic categorization processes in the 'poll tax riot'. Human Relations, 53, 247-273. https://doi.org/10.1177/a010563

Stott, C., Drury, J., \& Reicher, S. (2017). On the role of a social identity analysis in articulating structure and collective action: The 2011 riots in Tottenham and Hackney. British Journal of Criminology, 57(4), 964-981. https://doi.org/10.1093/bjc/ azw036

Stott, C., Ho, L., Radburn, M., Chan, Y., Kyprianides, A., \& Saavedra Morales, P. (2020). Patterns of 'disorder' during the 2019 protests in Hong Kong: Policing, social identity, intergroup dynamics and radicalisation. Policing: An International Journal of Policy and Practice, 14(4), 814-835. https://doi.org/10.1093/police/paaa073

Taylor, D. B. (2020, July 10). George Floyd protests: A timeline. New York Times. https://www.nytimes.com/article/georg e-floyd-protests-timeline.html

van Zomeren, M., Kutlaca, M., \& Turner-Zwinkels, F. (2018). Integrating who "we" are with what "we" (will not) stand for: A further extension of the Social Identity Model of Collective Action. European Review of Social Psychology, 29(1), 122-160. https://doi.org/10.1080/10463283.2018.1479347

Waddington, P. A. (1993). Dying in a ditch: The use of police powers in public order. International Journal of the Sociology of Law, 21, 335.

Wormwood, J. B., Lynn, S. K., Barrett, L. F., \& Quigley, K. S. (2016). Threat perception after the Boston Marathon bombings: The effects of personal relevance and conceptual framing. Cognition and Emotion, 30(3), 539-549. https://doi. org/10.1080/02699931.2015.1010487

\section{Supporting Information}

Additional Supporting Information may be found in the online version of this article at the publisher's web site:

Appendix S1. Disorder related arrestees in Greater Manchester.

Appendix S2. Disorder-related crime typology in August 2011.

Figure S1. Proximity of Salford and Manchester City Center.

Figure S2. Salford Precinct and environs.

Figure S3. Map of home addresses of 197 people charged with riot-related offences at Manchester City Magistrates Court up until 23 August 2011, plotted against levels of deprivation (IMD score) by Super Output Areas.

Figure S4. Table of arrestees from Greater Manchester and IMD decile for their area of residence who were charged and sentenced for disorder related offences in August 2011.

Figure S5. Disorder related crime by local authority area, by type of crime for major incidents in August 2011. 